\title{
Removal of Antimony(III) from Aqueous Solution by Using Grey and Red Erzurum Clay and Application to the Gediz River Sample
}

\author{
Şerif Targan, Vedia Nüket Tirtom, and Birsen Akkuş \\ Celal Bayar University, Sciences and Art Faculty, Department of Chemistry, 45140 Manisa, Turkey \\ Correspondence should be addressed to Vedia Nüket Tirtom; nuket.tirtom@cbu.edu.tr
}

Received 6 June 2013; Accepted 17 August 2013

Academic Editors: A. Niazi, A. Senthil Kumar, and A. Szemik-Hojniak

Copyright (C) 2013 Şerif Targan et al. This is an open access article distributed under the Creative Commons Attribution License, which permits unrestricted use, distribution, and reproduction in any medium, provided the original work is properly cited.

\begin{abstract}
The removal of $\mathrm{Sb}$ (III) from waste water is achieved in batch system by using grey and red Erzurum (Oltu) clay which are cheap and natural adsorbents. Adsorption experiments were studied. For this purpose, various important parameters such as contact time, $\mathrm{pH}$, and temperature were examined on the adsorption of $\mathrm{Sb}(\mathrm{III})$ ions onto grey and red Erzurum (Oltu) clay. Decreasing amount of $\mathrm{Sb}$ (III) ions in the solutions by adsorption was determined with differential pulse anodic stripping voltammetry (DPASV) method. Langmuir and Freundlich isotherms for the adsorption processes were drawn. The adsorption was demonstrated in similarity with Langmuir model. The maximum adsorption capacity of red Erzurum clay for $\mathrm{Sb}(\mathrm{III})$ was found to be $9.15 \mathrm{mg} / \mathrm{g}$. Also, surface of the adsorbent was characterized by using FTIR spectroscopy. Red Erzurum clay was applied on real sample (Gediz River), and 72.6\% adsorption was obtained.
\end{abstract}

\section{Introduction}

Heavy metal ions such as $\mathrm{Sb}(\mathrm{III})$ are toxic and carcinogenic at relatively low concentrations. Antimony has been extensively used in lead alloys, battery grids, bearing metal, cable sheathing, plumber's solder, pewter, ammunition, sheet, and pipe. Among the most important uses of antimony in nonmetal products are textiles, paints and lacquers, rubber compounds, ceramic enamels, glass and pottery abrasives phosphorus (a beryllium replacement), and certain types of matches $\left(\mathrm{SbCl}_{3}\right)$ $[1,2]$. US EPA and EU have established 6 and $10 \mu \mathrm{gL}^{-1}$, respectively, of maximum permissible $\mathrm{Sb}$ concentrations in drinking water $[3,4]$. In natural water, Sb mainly exists in the inorganic forms of $\mathrm{Sb}(\mathrm{III})$ and $\mathrm{Sb}(\mathrm{V})$ [5]. Antimony(III) is reported to be 10 times more toxic than $\mathrm{Sb}(\mathrm{V})$ [6-9]. When redox speciation determinations are performed, most studies report the dominance of $\mathrm{Sb}(\mathrm{V})$ under oxic conditions. However, the presence of significant proportions of $\mathrm{Sb}$ (III) is sometimes detected [10]. The analytical techniques more commonly used for the characterisation of aqueous antimony species are hydride generation methods coupled with AAS, AES, and MS detection systems. A variety of electrochemical methods have also been used for determination of total antimony in natural water samples. Determination of total antimony by differential pulse anodic stripping voltammetry (DPCSV) has been described by a few authors [11-14]. Niedzielski and Siepak presents a comparative description of different methods of determination of arsenic, antimony, and selenium: spectrophotometric, electroanalytical (voltamperometry), activation analysis, atomic fluorescence, and the methods of inductive or microwave-induced plasma in combination with different detection methods (emission or mass spectrometry) [15]. A number of methods have been used for the removal of antimony. These include reduction and precipitation [16], solvent extraction [17], ion exchange [18], reverse osmosis [19], membrane filtration [20], sorption in fixed-bed column [21], and biosorption [22, 23]. On the other hand, adsorption method is more effective in reducing toxic metal concentration $[24,25]$. The adsorption systems have many advantages of simplicity, fastness, and suitability for water and wastewater containing moderate and low concentrations of metals. Moreover, adsorbents must have a large surface area; a chemical nature and polarity of the adsorbent surface influence the attractive forces between the adsorbent and 
adsorbate [26-28]. Clay materials possess a layered structure and are considered as host materials [29]. Natural clay minerals are well known and familiar to mankind from the earliest days of civilization. Because of their low cost, abundance in most continents of the world, high adsorption properties, and potential for ion-exchange, clay materials are strong candidates as adsorbents. Abollino et al. have observed that $\mathrm{Na}-$ montmorillonite adsorbs $\mathrm{Cd}, \mathrm{Cr}, \mathrm{Cu}, \mathrm{Mn}, \mathrm{Ni}, \mathrm{Pb}$, or $\mathrm{Zn}$ even when organic substances (bonds) are present [30]. $\mathrm{Cd}, \mathrm{Cr}, \mathrm{Cu}$, $\mathrm{Ni}, \mathrm{Pb}$, and $\mathrm{Zn}$ were adsorbed on mineral clays from solutions with several concentrations by Covelo et al. [31].

In this study, we characterized grey and red Erzurum clay and used it to remove the toxic metal ions such as $\mathrm{Sb}(\mathrm{III})$ from aqueous solution in batch adsorption system. The $\mathrm{Sb}$ (III) adsorption of the grey and red Erzurum clay was examined in an aqueous solution. The effects of contact time, $\mathrm{pH}$, and temperature on the adsorption capacity were carried out. This method was applied on the real sample.

\section{Experimental}

2.1. Reagent. All reagents were of analytical grade. $\mathrm{SbCl}_{3}$ was supplied from Merck (Darmstadt, Germany). The following buffer solutions were used at a concentration of $0.1 \mathrm{~mol} \mathrm{~L}^{-1}$ to adjust the $\mathrm{pH}$ : citric acid/sodium citrate buffer ( $\mathrm{pH} 3.0$ ), acetic acid/sodium acetate (pH 4.0-6.0). Grey and red Erzurum clay was obtained from Erzurum (Oltu) in Turkey.

2.2. Instruments. Antimony (III) concentration measurements were carried out using Metrohm 746 VA Trace Analyzer differential pulse anodic stripping voltammetry. A conventional three-electrode system, comprising a mediumsized hanging mercuric drop electrode, with a surface area of $1.8 \mathrm{~mm}^{2}$, a platinum wire counter electrode, and an $\mathrm{Ag} / \mathrm{AgCl}$ (in saturated $\mathrm{KCl}$ ) reference electrode was used in all experiments. The reported potentials were referred to the $\mathrm{Ag} / \mathrm{AgCl}$ electrode. Solutions were deoxygenated with high purity nitrogen for $220 \mathrm{~s}$ prior to each experiment, and it was performed under a nitrogen atmosphere. The $\mathrm{pH}$ of solution was measured with a Hanna P211 microprocessor $\mathrm{pH}$ meter using a combined glass-calomel electrode. The shaking was carried out in a termostated electronic shaker Labart SH-5. X-ray analyses was carried out using JSDX $100 \mathrm{~S} 4$ Jeol X-Ray diffractometer.

2.3. Method. Stock solutions $\left(1000 \mathrm{mg} \mathrm{L}^{-1}\right)$ of $\mathrm{Sb}(\mathrm{III})$ were prepared by dissolving $0.9336 \mathrm{~g} \mathrm{SbCl}_{3}$ diluted to $500 \mathrm{~mL}$ with $5.0 \mathrm{M} \mathrm{HCl}$. Standard solutions of antimony at required concentrations were prepared by appropriate dilution. The $\mathrm{pH}$ of the solutions was adjusted by using citric acid/sodium citrate, acetic acid/sodium acetate. The sample solution $(5.0 \mathrm{~mL})$ containing $10 \mathrm{~mL} 0.6 \mathrm{M} \mathrm{HCl}$ supporting electrolyte media and $10 \mathrm{mg} \mathrm{L}^{-1}$ of $\mathrm{Sb}(\mathrm{III})$ was transferred into the voltammetric cell, and $10 \mathrm{~s}$ after addition of $\mathrm{Sb}(\mathrm{III})$, the stirrer was switched on and the solution was purged with nitrogen gas for $220 \mathrm{~s}$. The accumulation potential $(-190 \mathrm{mV})$ was applied to a fresh HMDE for $60 \mathrm{~s}$ whilst stirring the solution. Following the accumulation period, the stirrer was stopped, and

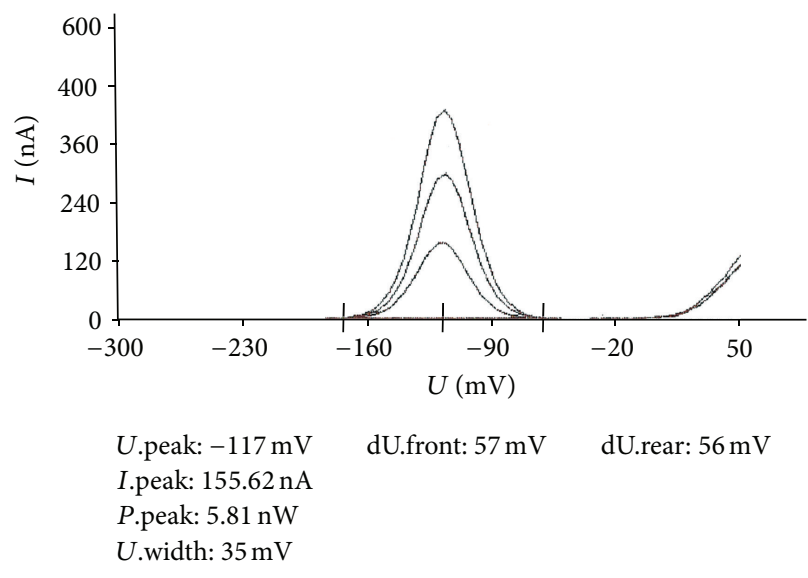

FIGURE 1: $10 \mathrm{ppm}$ of $\mathrm{Sb}$ (III) of the standard addition voltammogram.

after $5 \mathrm{~s}$ the voltammogram was recorded by applying a negative-going linear sweep scan from -300 to $+50 \mathrm{mV}$ the $\mathrm{Ag} / \mathrm{AgCl}$ reference electrode under the scan rate of $10 \mathrm{mV} \mathrm{s}^{-1}$ (Figure 1). The peak current for $\mathrm{Sb}(\mathrm{III})$ was measured at about $-190 \mathrm{mV}$ at 5 and $14 \mathrm{~min}$ after addition of antimony. A blank solution without antimony was used to obtain the blank peak current. The detection limits for determination of $\mathrm{Sb}$ (III) were $7.0 \mathrm{ng} / \mathrm{mL}$.

2.4. Characterization of Grey and Red Erzurum Clay. FTIR analyses were carried out on the grey and red Erzurum Clay using Perkin Elmer FTIR System Spectrum BX spectrophotometer. Samples for FTIR determination were dried and ground with spectral grade $\mathrm{KBr}$ in an agate mortar. A fixed amount of sample $(1 \% \mathrm{w}: \mathrm{w})$ in $\mathrm{KBr}$ was used to prepare the pellet. All FTIR measurements were carried out at room temperature.

2.5. Batch Adsorption Experiments. Adsorption experiments were carried out in batch technique. $0.50 \pm 0.02 \mathrm{~g}$ of each adsorbent (grey and red Erzurum clay) was put into beaker containing $50 \mathrm{~mL}$ of $200 \mathrm{mg} \mathrm{L}^{-1} \mathrm{Sb}$ (III) solution (in $5.0 \mathrm{M}$ $\mathrm{HCl}$ ), and the suspension was stirred. After decantation, the concentration of $\mathrm{Sb}(\mathrm{III})$ was analyzed by differential pulse anodic stripping voltammetry method. The amount of $\mathrm{Sb}$ (III) retained by the solid sorbent was measured by difference. The effect of contact time was studied 15-300 min. The effect of $\mathrm{pH}$ on $\mathrm{Sb}$ (III) adsorption was studied by using pH $3.0(0.1 \mathrm{M}$ citric acid- $0.1 \mathrm{M}$ sodium citrate) and $\mathrm{pH}$ 4.0-6.0 (0.1 M $\mathrm{CH}_{3} \mathrm{COOH}-0.1 \mathrm{M} \mathrm{NaCH} \mathrm{N}_{3} \mathrm{COO}$ ) buffer systems. Isotherm studies were conducted with a constant grey and red Erzurum clay weight $(0.50 \pm 0.02 \mathrm{~g})$ and varying initial concentrations of $\mathrm{Sb}$ (III) in the range of $10-50 \mathrm{mg} \mathrm{L}^{-1}$. All the experiments were carried out twice. The percentage adsorption of antimony on adsorbate from aqueous solution was computed as follows:

$$
\operatorname{Adsorption}(\%)=\frac{C_{\mathrm{int}}-C_{\mathrm{fin}}}{C_{\mathrm{int}}} \times 100 \text {. }
$$


TABLE 1: X-ray Analyses for gray and red Erzurum clay.

\begin{tabular}{lcc}
\hline Compound & Grey clay (\%) & Red clay (\%) \\
\hline $\mathrm{SiO}_{2}$ & 55.36 & 58.17 \\
$\mathrm{Al}_{2} \mathrm{O}_{3}$ & 11.06 & 13.22 \\
$\mathrm{Fe}_{2} \mathrm{O}_{3}$ & 5.85 & 10.06 \\
$\mathrm{CaO}$ & 8.6 & 5.39 \\
$\mathrm{MgO}$ & 3.0 & 1.52 \\
$\mathrm{SO}_{3}{ }^{2-}$ & 0.49 & 0.09 \\
$\mathrm{Na}_{2} \mathrm{O}$ & 2.7 & 1.74 \\
$\mathrm{~K}_{2} \mathrm{O}$ & 2.41 & 0.23 \\
$\mathrm{Cl}^{-}$ & 0.16 & - \\
\hline
\end{tabular}

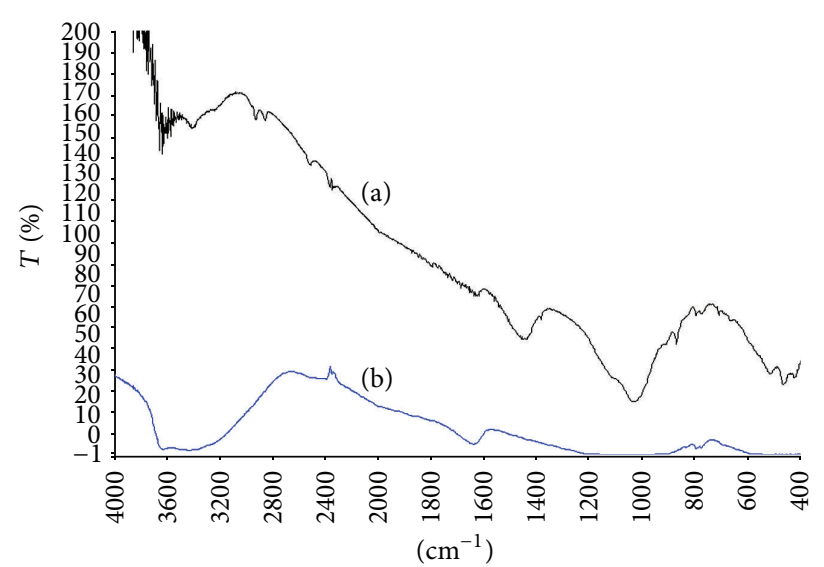

(a) Grey Erzurum clay

(b) Grey Erzurum clay with $\mathrm{Sb}^{3+}$

FIGURE 2: Infrared spectra of grey Erzurum clay.

The amount of metal ion adsorbed was calculated according to the following equation:

$$
q_{e}=\frac{C_{\text {int }}-C_{\text {fin }}}{W} \times V,
$$

where $C_{\text {int }}$ is the initial $\mathrm{Sb}$ (III) concentration $\left(\mathrm{mg} \mathrm{L}^{-1}\right), C_{\text {fin }}$ is the final $\mathrm{Sb}$ (III) concentration $\left(\mathrm{mg} \mathrm{L}^{-1}\right), V$ is the volume of the $\mathrm{Sb}(\mathrm{III})$ solution (L), and $W$ is the weight of the grey and red Erzurum clay $(\mathrm{g})$.

\section{Results and Discussion}

3.1. X-Ray Analysis. The X-ray analysis for the grey and red Erzurum clay is shown in Table 1.

3.2. FTIR Spectroscopy. The FTIR spectra were shown of the grey and red Erzurum clay in Figures 2 and 3. The IR spectrum of grey and red Erzurum clay exhibits an adsorption band from 3600 to $3200 \mathrm{~cm}^{-1}$ due to stretching vibration of the $\mathrm{Si}-\mathrm{OH}, \mathrm{Al}-\mathrm{OH}$ and other metal hydroxide groups. In the spectrum of grey and red Erzurum clay, the definition of a peak near $1600 \mathrm{~cm}^{-1}$ is attributed to the vibration of water molecules retained in the silica or alumina matrix. The peaks at $469 \mathrm{~cm}^{-1}$ may be defined as asymmetric stretching modes of $\mathrm{Si}-\mathrm{O}-\mathrm{Si}$ bond.

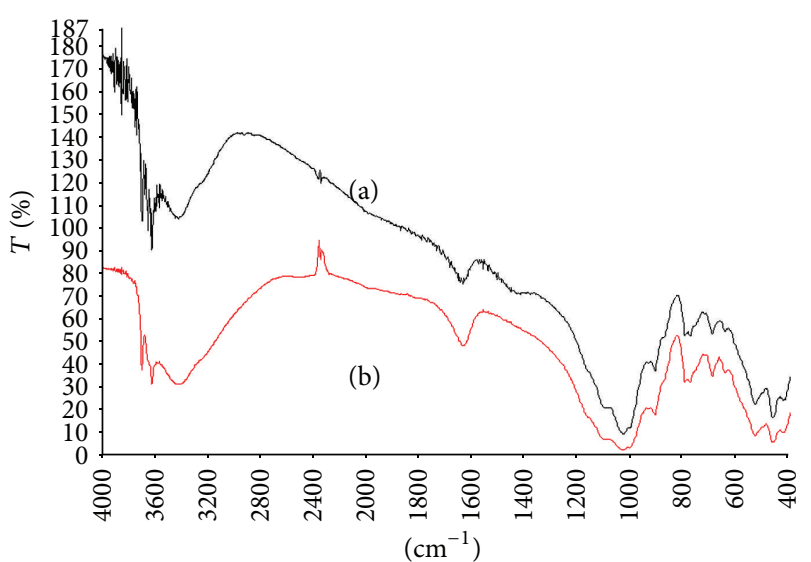

(a) Red Erzurum clay

(b) Red Erzurum clay with $\mathrm{Sb}^{3+}$

FIGURE 3: Infrared spectra of red Erzurum clay.

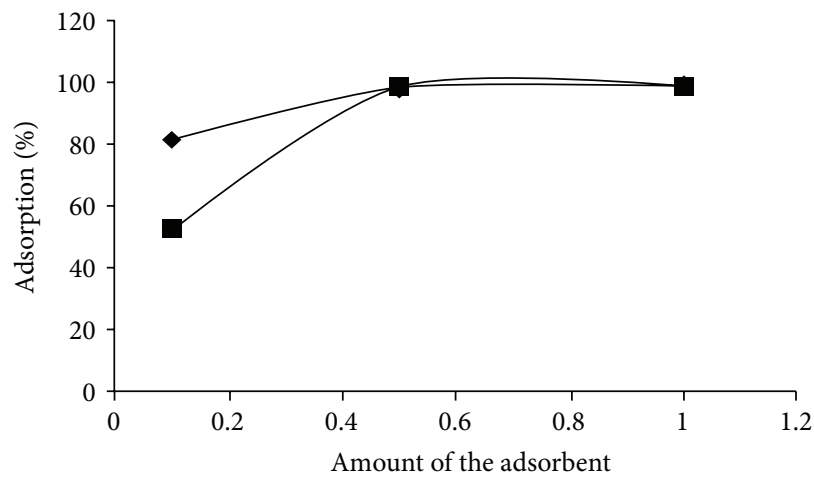

FIGURE 4: Effect of the adsorbent dose on the adsorption capacities of grey and red Erzurum clay for Sb(III) ions ( $\downarrow$ : grey clay, $\mathbf{\square}$ : red clay).

3.3. Effect of the Adsorbent Dose and Particle Size on Sorption of Antimony(III). The effect of the adsorbent dose on the capacity of the antimony ions Sb(III) was shown in Figure 4. The amount of the adsorbent was varied in the range $0.1-1.0 \mathrm{~g}$. $50 \%$ and $81 \%$ adsorption capacity was observed for $0.5 \mathrm{~g}$ of the red and grey clay, respectively. $99 \%$ adsorption was observed for $1 \mathrm{~g}$ of red and grey Erzurum clay. Adsorbent dose was chosen as $0.5 \mathrm{~g}$ based on these results. The adsorbent particle size was varied in the range of 100-500 mesh. 97\% adsorption capacity was found for 100 mesh of adsorbent dose. Adsorption capacity was increased to $99 \%$ for 500 mesh size. Adsorbent particle size was chosen to be 500 mesh.

3.4. Effect of Contact Time on Sorption of Antimony(III). The effect of the contact time on the capacity of the antimony ions $\mathrm{Sb}$ (III) was shown in Figure 5. The contact time was varied in the range 15-300 minute, and the initial metal concentration was fixed at $200 \mathrm{mg} \mathrm{L}^{-1}$. As shown in Figure 5, it was remarkable that an increase in the contact time for $\mathrm{Sb}$ (III) ions led to an increase in the adsorption capacity of grey and red Erzurum clay. After 45 minutes adsorption was observed in 


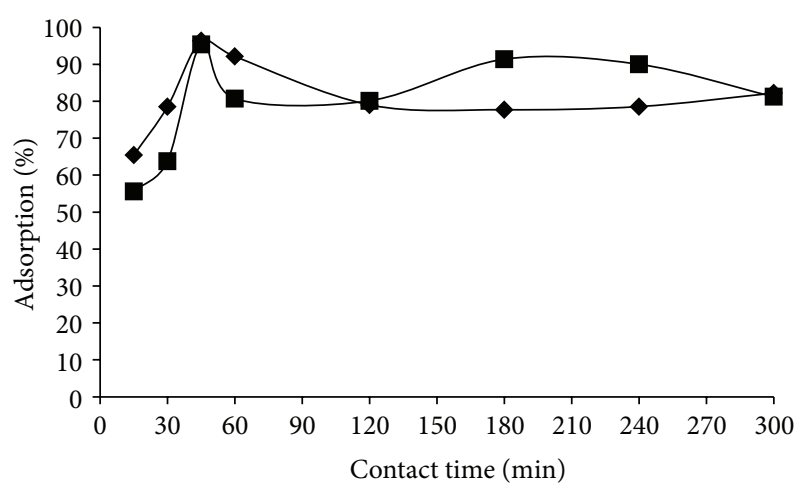

FIGURE 5: Effect of the adsorption time on the adsorption capacities of grey and red Erzurum clay for Sb(III) ions ( $\$$ : grey clay, $\mathbf{a}$ : red clay).

the range of $80-95 \%$. Optimum period was chosen as 45 minute for the adsorption of the grey and red Erzurum clay. Thus, the equilibrium time was maintained $45 \mathrm{~min}$. in subsequent adsorption studies. There are several parameters which determine sorption rate, like structural properties of the adsorbent (size, surface area, porosity), metal ion properties, initial concentration of metal ions, $\mathrm{pH}$, or chelate formation rate. Therefore, it is difficult to make a comparison between adsorbents [32].

3.5. Effect of pH on Sorption of Antimony(III). The $\mathrm{pH}$ of the aqueous solution is an important parameter in adsorption processes. To prevent precipitation, experiments were carried out at $\mathrm{pH}<6.0$ to ensure solubility of metal ions [33-35]. At higher $\mathrm{pH}$ values decrease in adsorption efficiency is due to the formation of soluble hydroxylated complexes of the antimony and their competition with the active sites, and as a consequence, adsorption would decrease [1]. The adsorption of $\mathrm{Sb}$ (III) ions was highly dependent on the $\mathrm{pH}$ of the metal solution because $\mathrm{pH}$ can affect the solubility of the metal ions and at the same time influence the ionization state of the functional groups existing on the adsorbent [36]. The effect of $\mathrm{pH}$ on the adsorption of antimony (III) ions was studied at different $\mathrm{pH}$ values (1.0-6.0) using grey and red Erzurum clay $(500 \mathrm{mg})$ at constant metal ion concentration $\left(200 \mathrm{mg} \mathrm{L}^{-1}\right)$. $\mathrm{pH}$ selection in the range of 1.0-6.0 was rationalized by the fact that while $\mathrm{pH}>2.0$ could result in the formation of metal hydroxide precipitates, the results indicate that the maximum uptake of $\mathrm{Sb}$ (III) ions takes place at $\mathrm{pH}$ 1.5. Similar results have also been reported for the sorption of antimony [37-39]. Effect of $\mathrm{pH}$ on sorption of $\mathrm{Sb}$ (III) ions was shown in Figure 6. The results were shown, which indicated that sorption of $\mathrm{Sb}$ (III) on grey and red Erzurum clay decreased above $\mathrm{pH} 2$. It was observed from the graph of the variation of the concentrations of the antimony(III) species with $\mathrm{pH}$ obtained using the visual Minteq program [40] (Figure 7) that after $\mathrm{pH} 2$ species $\mathrm{SbO}^{+}$and $\mathrm{Sb}(\mathrm{OH})$ decreas while $\mathrm{Sb}(\mathrm{OH})_{3}$ increases, which explains the weak sorption after $\mathrm{pH} 2$.

Although high adsorption was observed at low $\mathrm{pH}$, we carried out all studies at natural water's $\mathrm{pH}$ without using any buffer solution.

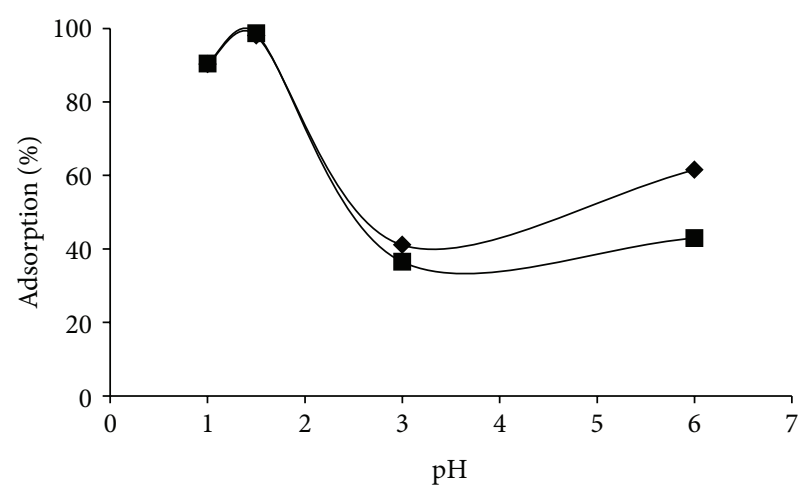

FIGURE 6: Effect of the $\mathrm{pH}$ on the adsorption capacities of grey and red Erzurum clay for $\mathrm{Sb}$ (III) ions ( $\$$ : grey Erzurum clay, $\mathbf{-}$ red Erzurum clay) $\left(50 \mathrm{~mL}, 200 \mathrm{mg} \mathrm{L}^{-1}, 0.5 \mathrm{~g}\right.$ adsorbent, and $45 \mathrm{~min}$. contact time).

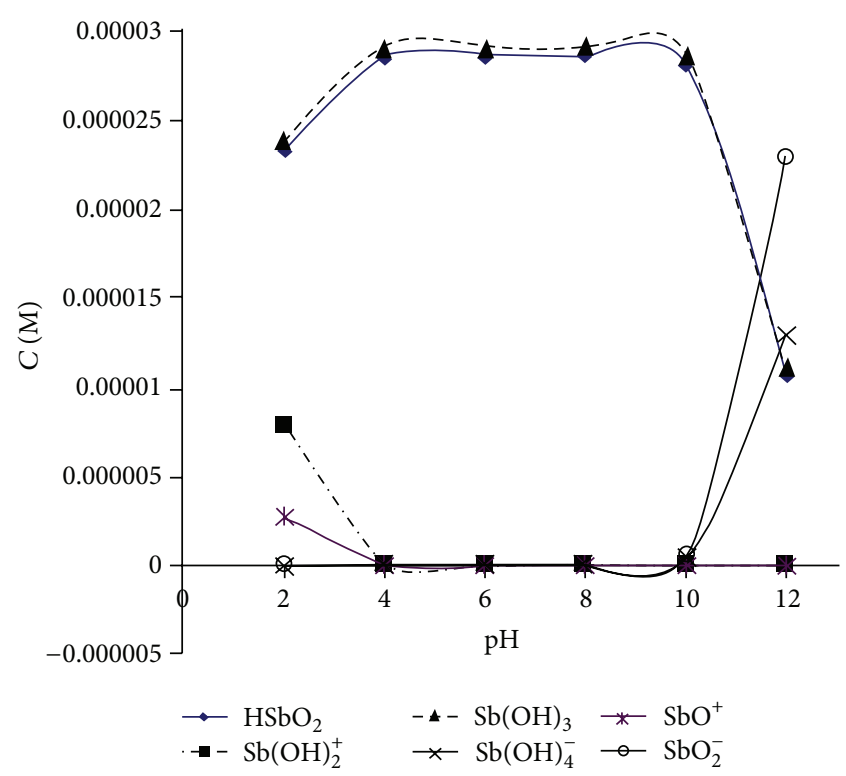

FIgURE 7: The graph obtained by using the visual Minteq programme for $\mathrm{Sb}(\mathrm{III})$ species in the presence of $0.1 \mathrm{M} \mathrm{HCl}$ and $0.1 \mathrm{M}$ $\mathrm{KCl}$ in the $\mathrm{pH}$ range $2-12$.

3.6. Effect of Temperature on Sorption of Sb(III) Ions. In this study, the adsorption process was assessed at different temperatures between 10 and $40^{\circ} \mathrm{C}$. Figure 8 shows that the temperature had no important effect on the adsorption of $\mathrm{Sb}$ (III). Maximum adsorption was observed at $25^{\circ} \mathrm{C}$. It can be seen in Figure 8 that over $25^{\circ} \mathrm{C}$ adsorption was decreased a little. As seen in Figure 8, adsorption capacity was decreased a little with an increase in temperature. With increasing temperature, the attractive forces between the grey and red Erzurum clay surface and metal ion are weakened, and then sorption decreases. Adsorption temperature was chosen at $25^{\circ} \mathrm{C}$.

3.7. Adsorption Isotherm Models. Adsorption isotherms are used to express the surface properties and affinity of the adsorbent and can also be used to compare the adsorption 
TABLE 2: Langmuir and Freundlich isotherm constants for adsorption of Sb(III) ions on grey and red Erzurum clay.

\begin{tabular}{lccccr}
\hline \multirow{2}{*}{ Temperature } & \multicolumn{2}{c}{ Langmuir isotherm constants } & \multicolumn{3}{c}{ Freundlich isotherm constants } \\
& $Q\left(\mathrm{mg} \mathrm{g}^{-1}\right)$ & $b$ & $R^{2}$ & $n$ & $K_{F}$ \\
\hline $25^{\circ} \mathrm{C}$ & 9.15 & 71.4 & 0.9996 & 28.08 & 9.23 \\
$40^{\circ} \mathrm{C}$ & 8.58 & 33.3 & 0.9988 & 20.08 & 9.9555 \\
\hline
\end{tabular}

TABLE 3: Thermodynamic parameters for Sb(III) ions.

\begin{tabular}{lccc}
\hline Adsorbent & $\Delta G^{\circ}\left(\mathrm{kJ} \mathrm{mol}^{-1}\right)$ & $\left.\Delta H^{\circ}(\mathrm{kJ} \mathrm{mol})^{-1}\right)$ & $\Delta S^{\circ}\left(\mathrm{kJ} \mathrm{mol}{ }^{-1} \mathrm{~K}\right)$ \\
\hline Grey Erzurum clay & -202.439 & 23.744 & 0.796 \\
Red Erzurum clay & -200.258 & 55.403 & 0.903 \\
\hline
\end{tabular}

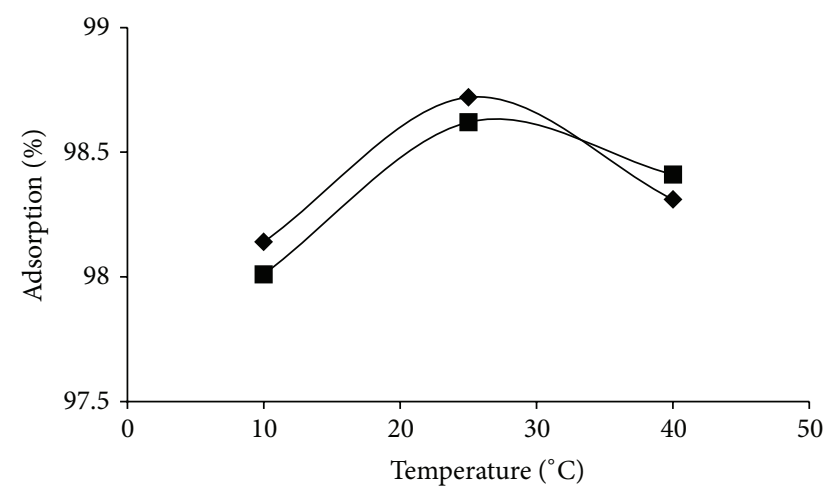

FIGURE 8: Effect of the temperature on the adsorption capacities of grey and red Erzurum clay $\mathrm{Sb}(\mathrm{III})$ ions ( $\$$ : grey Erzurum clay, $\mathbf{\square}$ : red Erzurum clay) ( $50 \mathrm{~mL}, 0.5 \mathrm{~g}$ adsorbent, and $45 \mathrm{~min}$. for $\mathrm{Sb}(\mathrm{III})$ ).

capacities of the sorbents for pollutants in aqueous solutions. In this study, the two adsorption isotherm models, Langmuir and Freundlich isotherms, were selected to fit the equilibrium data. The Langmuir isotherm assumes a surface with homogeneous binding sites, equivalent sorption energies, and no interaction between sorbed species [41]. In mathematical form, it is written as

$$
\frac{C_{e}}{q_{e}}=\frac{1}{Q \cdot b}+\frac{C_{e}}{Q},
$$

where $C_{e}$ is equilibrium concentration of the metal $\left(\mathrm{mg} \mathrm{L}^{-1}\right)$ and $q_{e}$ is the amount of the metal adsorbed (mg) per unit of the adsorbent. When $C_{e} / q_{e}$ is plotted against $C_{e}$, a straight line with a slope of $1 / Q$ and intercept was obtained, which shows that the adsorption of $\mathrm{Sb}$ (III) follows Langmuir isotherm model. The Langmuir parameters $Q\left(\mathrm{mgg}^{-1}\right)$ and $b\left(\mathrm{~L} \mathrm{mg}^{-1}\right)$ were calculated from the slope and intercept and were given in Table 2. According to the results, Langmuir model was found to describe adsorption successfully than Freundlich model isotherm in respect to linearity coefficients obtained for both models $\left(R^{2}=0.9996\right.$ and 0.9555) (Figure 9 and Table 2) for $\mathrm{Sb}(\mathrm{III})$ ions. The Langmuir model predicts the formation of a monolayer of the adsorbate on the adsorbent surface [42]. In this study the maximum adsorption capacity of grey and red Erzurum clay for $\mathrm{Sb}(\mathrm{III})$ was determined as $9.15 \mathrm{mg} \mathrm{g}^{-1}$.

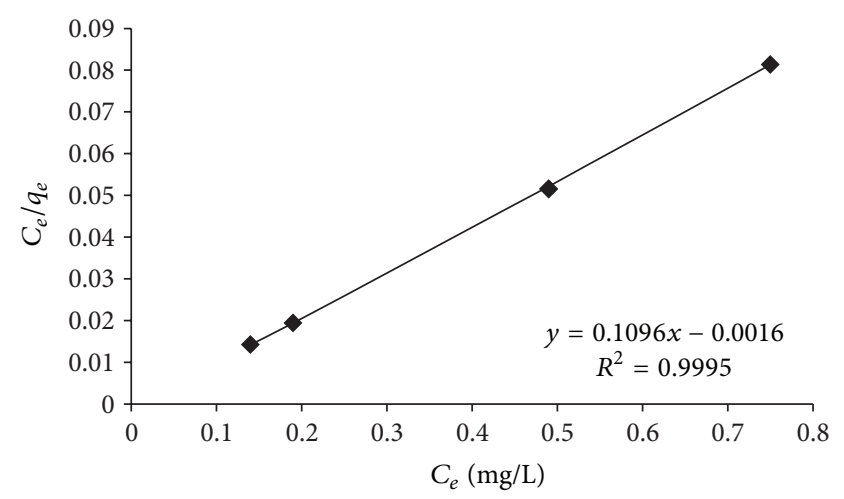

FIGURE 9: Langmuir plot for $\mathrm{Sb}$ (III) adsorption on red Erzurum clay at equilibrium $\left(10^{\circ} \mathrm{C}\right)$.

3.8. Adsorption Thermodynamics. To investigate the controlling mechanism of the adsorption processes, temperaturedependent distribution coefficient was computed as follows:

$$
K_{d}=\frac{C_{\mathrm{ad}}}{C_{e}},
$$

where $K_{d}$ is the equilibrium constant, $C_{\text {ad }}$ and $C_{e}$ are equilibrium concentrations $\left(\mathrm{mg} \mathrm{L}^{-1}\right)$ of $\mathrm{Sb}$ (III) on the adsorbent and in the solution, respectively. The adsorption process was also assessed at different temperatures between 10 and $40^{\circ} \mathrm{C}$. Temperature effects on adsorption were shown in Figure 8. Thermodynamic parameters including the change in free energy $\left(\Delta G^{\circ}\right)$, enthalpy $\left(\Delta H^{\circ}\right)$, and entropy $\left(\Delta S^{\circ}\right)$ were calculated from the following equation:

$$
\Delta G^{\circ}=-R T \ln K_{d}
$$

where $R$ is the universal gas constant $(8.314 \mathrm{~J} / \mathrm{mol} \mathrm{K}), T$ is the temperature $(\mathrm{K})$, and $K_{d}\left(q_{e} / C_{e}\right)$ is the distribution coefficient. The enthalpy $\left(\Delta H^{\circ}\right)$ and entropy $\left(\Delta S^{\circ}\right)$ parameters were estimated from the following Vant Hoff equation:

$$
\ln K_{d}=\frac{\Delta S^{\circ}}{R}-\frac{\Delta H^{\circ}}{R T} \text {. }
$$

Values of the standard Gibbs free energy change for the adsorption process obtained from (6) were listed in Table 3. 
TABLE 4: Application of Sb(III) removal in Gediz River samples using red Erzurum clay.

\begin{tabular}{|c|c|c|c|c|}
\hline & $\begin{array}{c}\mathrm{Sb}(\mathrm{III}) \\
\text { concentration } \\
\text { before removal } \\
(\mathrm{mg} / \mathrm{L}) \\
(n=3)\end{array}$ & $\begin{array}{c}\text { Remain } \\
\text { Sb(III) } \\
\text { concentration } \\
\text { (after removal) } \\
(\mathrm{mg} / \mathrm{L}) \\
(n=3)\end{array}$ & $\begin{array}{c}\text { Adsorbed } \\
\text { Sb(III) } \\
\text { concentration } \\
(\mathrm{mg} / \mathrm{L})\end{array}$ & $\%$ Adsorption \\
\hline Manisa, Muradiye Gediz River Bridge & $0.063 \pm 0.03$ & $0.034 \pm 0.05$ & 0.029 & 46.0 \\
\hline Karaçay & $0.559 \pm 0.06$ & $0.154 \pm 0.02$ & 0.405 & 72.6 \\
\hline Nif Stream & $0.014 \pm 0.03$ & $0.012 \pm 0.04$ & 0.002 & 14.3 \\
\hline
\end{tabular}

The positive value of $\Delta H\left(23.744 \mathrm{~kJ} \mathrm{~mol}^{-1}\right)$ and the positive value of $\Delta S^{\circ}=\left(0.796 \mathrm{~kJ} \mathrm{~K}^{-1} \mathrm{~mol}^{-1}\right)$ indicate that the adsorption processes are spontaneous at high temperatures for $\mathrm{Sb}$ (III) ions. The negative value of $\Delta G^{\circ}\left(-202.439 \mathrm{~kJ} \mathrm{~mol}^{-1}\right)$ shows an adsorption process proceeds spontaneously. $\Delta H^{\circ}$ $\left(55.403 \mathrm{~kJ} \mathrm{~mol}^{-1}\right), \Delta S^{\circ}=\left(0.903 \mathrm{~kJ} \mathrm{~K}^{-1} \mathrm{~mol}^{-1}\right)$, and $\Delta G^{\circ}=$ $\left(-200.258 \mathrm{~kJ} \mathrm{~mol}^{-1}\right)$ were found for red Erzurum clay.

3.9. Application of (III) Removal in Gediz River Samples. The physical and chemical parameters of water and the level of heavy metal concentration in water and sediment samples were analyzed in five different stations of Gediz River by Öner (2008) and Kayar (2003). The average level of some parameters is BOD: $67.7 \mathrm{mg} / \mathrm{L}, \mathrm{COD}: 88.7 \mathrm{mg} / \mathrm{L}, \mathrm{pH}: 7.6$, and turbidity: $440 \mathrm{mg} / \mathrm{L} \mathrm{SiO}_{2}$. In water samples, the metals in high level are $\mathrm{Pb}: 27.0 \pm 0.8 \% \mu \mathrm{g} / \mathrm{L}$ at Nif River, $\mathrm{Cr}$ : $48.9 \pm 0.9 \% \mu \mathrm{g} / \mathrm{L}$ at Muradiye Bridge, Cd: $12.1 \pm 0.6 \% \mu \mathrm{g} / \mathrm{L}$ at Istanbul Bridge, $\mathrm{Cu}: 90.2 \pm 0.4 \% \mu \mathrm{g} / \mathrm{L}$ at Muradiye Bridge, and Ni: $309.8 \pm 0.7 \% \mu \mathrm{g} / \mathrm{L}, \mathrm{Fe}: 914.1 \pm 0.3 \% \mu \mathrm{g} / \mathrm{L}$, and $\mathrm{Zn}: 208.3 \pm$ $0.5 \% \mu \mathrm{g} / \mathrm{L}$ in Karaçay [43]. According to the results obtained, the highest metal concentrations were found as $1.00 \mathrm{mg} / \mathrm{L} \mathrm{Pb}$ (Karaçay); 0.09 mg/L Cr, 2.70 mg/L Ba, 3.9 mg/L Al (Muradiye Bridge); $0.04 \mathrm{mg} / \mathrm{L} \mathrm{Cd}, 0.39 \mathrm{mg} / \mathrm{L} \mathrm{Cu}$ (Istanbul Bridge); $0.90 \mathrm{mg} / \mathrm{L} \mathrm{Ni}$ (Nif Çayı); and an average value of $1.00 \mathrm{mg} / \mathrm{L} \mathrm{Fe}$ and $3.15 \mathrm{mg} / \mathrm{L} \mathrm{Zn}$ (all stations) [44]. The quality of water is at the level of four, according to Water Pollution Control Regulations. Therefore, Gediz River was chosen for this study. The river waters were taken from 3 stations in the vicinity of Manisa, Muradiye Gediz River Bridge, the Karaçay, and Nif Stream. The $\mathrm{pH}$ of the samples were measured, 7.8, 8.2, and 7.4, respectively. $\mathrm{Sb}$ (III) level was measured by DPP-ASV. $\mathrm{Sb}$ (III) removal from Gediz River samples using optimized experimental parameters (contact time: 45 min., temperature: $25^{\circ} \mathrm{C}$ ) was studied. The results were given in Table 4 .

\section{Conclusions}

In this study, the equilibrium, thermodynamics of the adsorption of $\mathrm{Sb}$ (III) from aqueous solution using low cost adsorbent (grey and red Erzurum clay) were investigated using a batch system. The maximum adsorption capacity of grey and red Erzurum clay for $\mathrm{Sb}$ (III) was found to be $9.15 \mathrm{mg} / \mathrm{g} 25^{\circ} \mathrm{C}$. Based on a linearized correlation coefficient the Langmuir isotherm model gives better fit than the Freundlich isotherm model. Red Erzurum clay was used in real sample (Gediz River) for removal of $\mathrm{Sb}(\mathrm{III})$. In conclusion, grey and red
Erzurum clay have been proven to be effective adsorbents for removal of toxic metal ion such as $\mathrm{Sb}$ (III).

\section{List of Symbols}

$\Delta G^{\circ}$ : Energy change

$\Delta H^{\circ}$ : Enthalpy change

$\Delta S^{\circ}$ : Entropy change

$C_{e}:$ Equilibrium concentration

$C_{r}$ : Residual lead concentrations

$C_{\text {int }}$ : Initial $\mathrm{Pb}(\mathrm{II})$ concentration

$C_{\text {fin }}$ : Final $\mathrm{Pb}(\mathrm{II})$ concentration

$q_{e}: \quad$ The amount of the metal adsorbed

Q: Capacity of the adsorbent calculated from the slope of Langmuir isotherm

$b$ : Capacity of the adsorbent calculated from the intercept of Langmuir isotherm

$V: \quad$ Volume of the solution

$m$ : Amount of the adsorbent

$R: \quad$ Universal gas constant

$K$ : Temperature

$K_{d}:$ Distribution coefficient

$W:$ Weight of the adsorbent.

\section{References}

[1] A. Sari, D. Çitak, and M. Tuzen, "Equilibrium, thermodynamic and kinetic studies on adsorption of $\mathrm{Sb}$ (III) from aqueous solution using low-cost natural diatomite," Chemical Engineering Journal, vol. 162, no. 2, pp. 521-527, 2010.

[2] N. Khalid, S. Ahmad, A. Toheed, and J. Ahmed, "Potential of rice husks for antimony removal," Applied Radiation and Isotopes, vol. 52, no. 1, pp. 31-38, 2000.

[3] CEC, Council of the European Communities, Council Directive Relating to the Quality of Water Intended for Human Consumption, 1980.

[4] USEPA, Antimony: An Environmental And Health Effects Assessment, US Environmental Protection Agency, Office of drinking water, Washington, DC, USA, 1984.

[5] M. Filella, N. Belzile, and Y.-W. Chen, "Antimony in the environment: a review focused on natural waters II. Relevant solution chemistry," Earth-Science Reviews, vol. 59, no. 1-4, pp. 265-285, 2002.

[6] N. Gurnani, A. Sharma, and G. Tulukder, "Effects of antimony on cellular systems in animals: a review," Nucleus, vol. 37, pp. 7196, 1994. 
[7] T. Gebel, "Aresnic and antimony: comparative approach on mechanistic toxicology," Chemico-Biological Interactions, vol. 107, no. 3, pp. 131-144, 1997.

[8] K. Oorts, E. Smolders, F. Degryse et al., "Solubility and toxicity of antimony trioxide $\left(\mathrm{Sb}_{2} \mathrm{O}_{3}\right)$ in soil," Environmental Science and Technology, vol. 42, no. 12, pp. 4378-4383, 2008.

[9] P. Smichowski, Y. Madrid, and C. Cámara, "Analytical methods for antimony speciation in waters at trace and ultratrace levels. A review," Fresenius' Journal of Analytical Chemistry, vol. 360, no. 6, pp. 623-629, 1998.

[10] M. Filella, N. Belzile, and Y. Chen, "Antimony in the environment: a review focused on natural waters," Earth-Science Reviews, vol. 57, no. 1-2, pp. 125-176, 2002.

[11] F. Quentel and M. Filella, "Determination of inorganic antimony species in seawater by differential pulse anodic stripping voltammetry: stability of the trivalent state," Analytica Chimica Acta, vol. 452, no. 2, pp. 237-244, 2002.

[12] C. A. Woolever, D. E. Starkey, and H. D. Dewald, "Differential pulse anodic stripping voltammetry of lead and antimony in gunshot residues,' Forensic Science International, vol. 102, no. 1, pp. $45-50,1999$.

[13] R. Guin, S. K. Das, and S. K. Saha, "The anion exchange behavior of Te and Sb," Journal of Radioanalytical and Nuclear Chemistry, vol. 230, no. 1-2, pp. 269-271, 1998.

[14] A. M. Bond, S. Kratsis, and O. M. G. Newman, "Combined use of differential pulse adsorptive and anodic stripping techniques for the determination of antimony(III) and antimony (V) in zinc electrolyte," Analytica Chimica Acta, vol. 372, no. 3, pp. 307-314, 1998.

[15] P. Niedzielski and M. Siepak, "Analytical methods for determining arsenic, antimony and selenium in environmental samples," Polish Journal of Environmental Studies, vol. 12, no. 6, pp. 653667, 2003.

[16] K. Gannon and D. J. Wilson, "Removal of antimony from aqueous solutions," Separation Science and Technology, vol. 21, no. 5, pp. 475-493, 1986.

[17] W.-M. Mok and C. M. Wai, "Distribution and mobilization of arsenic and antimony species in the Coeur D'Alene River, Idaho," Environmental Science and Technology, vol. 24, no. 1, pp. 102-108, 1990.

[18] R. Guin, S. K. Das, and S. K. Saha, "The anion exchange behavior of Te and Sb," Journal of Radioanalytical and Nuclear Chemistry, vol. 230, no. 1-2, pp. 269-271, 1998.

[19] M. Kang, M. Kawasaki, S. Tamada, T. Kamei, and Y. Magara, "Effect of $\mathrm{pH}$ on the removal of arsenic and antimony using reverse osmosis membranes," Desalination, vol. 131, no. 1-3, pp. 293-298, 2000.

[20] T. Saito, S. Tsuneda, A. Hirata et al., "Removal of antimony (III) using polyol-ligand-containing porous hollow-fiber membranes," Separation Science and Technology, vol. 39, no. 13, pp. 3011-3022, 2004.

[21] A. Bakir, P. Mcloughlin, S. A. M. Tofail, and E. Fitzgerald, "Competitive sorption of antimony with zinc, nickel, and aluminum in a seaweed based fixed-bed sorption column," Clean, vol. 37, no. 9, pp. 712-719, 2009.

[22] J. Tomko, M. Bačkor, and M. Štofko, "Biosorption of heavy metals by dry fungi biomass," Acta Chimica Slovenica, vol. 12, pp. 447-451, 2006.

[23] T. Pérez-Corona, Y. Madrid, and C. Cámara, "Evaluation of selective uptake of selenium ( $\mathrm{Se}(\mathrm{IV})$ and $\mathrm{Se}(\mathrm{VI}))$ and antimony
( $\mathrm{Sb}(\mathrm{III})$ and $\mathrm{Sb}(\mathrm{V}))$ species by baker's yeast cells (Saccharomyces cerevisiae)," Analytica Chimica Acta, vol. 345, no. 1-3, pp. 249-255, 1997.

[24] K. G. Bhattacharyya and S. S. Gupta, "Influence of acid activation on adsorption of $\mathrm{Ni}(\mathrm{II})$ and $\mathrm{Cu}(\mathrm{II})$ on kaolinite and montmorillonite: kinetic and thermodynamic study," Chemical Engineering Journal, vol. 136, no. 1, pp. 1-13, 2008.

[25] E. Demirbas, N. Dizge, M. T. Sulak, and M. Kobya, "Adsorption kinetics and equilibrium of copper from aqueous solutions using hazelnut shell activated carbon," Chemical Engineering Journal, vol. 148, no. 2-3, pp. 480-487, 2009.

[26] G. D. Sheng, D. D. Shao, Q. H. Fan, D. Xu, Y. X. Chen, and X. $\mathrm{K}$. Wang, "Effect of $\mathrm{pH}$ and ionic strength on sorption of $\mathrm{Eu}(\mathrm{III})$ to MX-80 bentonite: batch and XAFS study," Radiochimica Acta, vol. 97, no. 11, pp. 621-630, 2009.

[27] P. Chang, S. Yu, T. Chen, A. Ren, C. Chen, and X. Wang, "Effect of $\mathrm{pH}$, ionic strength, fulvic acid and humic acid on sorption of Th(IV) on Na-rectorite," Journal of Radioanalytical and Nuclear Chemistry, vol. 274, no. 1, pp. 153-160, 2007.

[28] V. C. Srivastava, I. D. Mall, and I. M. Mishra, "Adsorption thermodynamics and isosteric heat of adsorption of toxic metal ions onto bagasse fly ash (BFA) and rice husk ash (RHA)," Chemical Engineering Journal, vol. 132, no. 1-3, pp. 267-278, 2007.

[29] M. Ahmaruzzaman, "Adsorption of phenolic compounds on low-cost adsorbents: a review," Advances in Colloid and Interface Science, vol. 143, no. 1-2, pp. 48-67, 2008.

[30] O. Abollino, M. Aceto, M. Malandrino, C. Sarzanini, and E. Mentasti, "Adsorption of heavy metals on Na-montmorillonite. Effect of $\mathrm{pH}$ and organic substances," Water Research, vol. 37, no. 7, pp. 1619-1627, 2003.

[31] E. F. Covelo, F. A. Vega, and M. L. Andrade, "Sorption and desorption of $\mathrm{Cd}, \mathrm{Cr}, \mathrm{Cu}, \mathrm{Ni}, \mathrm{Pb}$ and $\mathrm{Zn}$ by a Fibric Histosol and its organo-mineral fraction," Journal of Hazardous Materials, vol. 159, no. 2-3, pp. 342-347, 2008.

[32] N. Ünlü and M. Ersoz, "Adsorption characteristics of heavy metal ions onto a low cost biopolymeric sorbent from aqueous solutions," Journal of Hazardous Materials, vol. 136, no. 2, pp. 272-280, 2006.

[33] B. K. Biswas, J.-I. Inoue, H. Kawakita, K. Ohto, and K. Inoue, "Effective removal and recovery of antimony using metalloaded saponified orange waste," Journal of Hazardous Materials, vol. 172, no. 2-3, pp. 721-728, 2009.

[34] K. G. Bhattacharyya and S. S. Gupta, "Kaolinite, montmorillonite, and their modified derivatives as adsorbents for removal of $\mathrm{Cu}(\mathrm{II})$ from aqueous solution," Separation and Purification Technology, vol. 50, no. 3, pp. 388-397, 2006.

[35] R. Watkins, D. Weiss, W. Dubbin, K. Peel, B. Coles, and T. Arnold, "Investigations into the kinetics and thermodynamics of $\mathrm{Sb}$ (III) adsorption on goethite $(\alpha-\mathrm{FeOOH})$," Journal of Colloid and Interface Science, vol. 303, no. 2, pp. 639-646, 2006.

[36] S. Tunali, A. Çabuk, and T. Akar, "Removal of lead and copper ions from aqueous solutions by bacterial strain isolated from soil," Chemical Engineering Journal, vol. 115, no. 3, pp. 203-211, 2006.

[37] N. Khalid, S. Ahmad, A. Toheed, and J. Ahmed, "Potential of rice husks for antimony removal," Applied Radiation and Isotopes, vol. 52, no. 1, pp. 31-38, 2000.

[38] G. Sheng, S. Wang, J. Hu et al., "Adsorption of $\mathrm{Pb}$ (II) on diatomite as affected via aqueous solution chemistry and temperature," Colloids and Surfaces A, vol. 339, no. 1-3, pp. 159-166, 2009. 
[39] Y.-H. Xu, A. Ohki, and S. Maeda, "Adsorption and removal of antimony from aqueous solution by an activated alumina. 1. Adsorption capacity of adsorbent and effect of process variables," Toxicological and Environmental Chemistry, vol. 80, no. 3-4, pp. 133-144, 2001.

[40] P. J. Gustafsson, Visual Minteq, ver. 2. 32, KTH Dept. of Land and Water Resources Engineering, Stockholm, Sweden, 2005.

[41] Y. Vijaya, S. R. Popuri, V. M. Boddu, and A. Krishnaiah, "Modified chitosan and calcium alginate biopolymer sorbents for removal of nickel (II) through adsorption," Carbohydrate Polymers, vol. 72, no. 2, pp. 261-271, 2008.

[42] H. L. Vasconcelos, T. P. Camargo, N. S. Gonçalves, A. Neves, M. C. M. Laranjeira, and V. T. Fávere, "Chitosan crosslinked with a metal complexing agent: synthesis, characterization and copper(II) ions adsorption," Reactive and Functional Polymers, vol. 68, no. 2, pp. 572-579, 2008.

[43] Ö. Öner and A. Çelik, "Investigation of some pollution parameters in water and sediment samples collected from the lower gediz river basin," Ekoloji, no. 78, pp. 48-52, 2011.

[44] V. N. Kayar and A. Celik, Determination of Some Pollution Parameters and Water Quality of Gediz River, Ekoloji, 2003. 

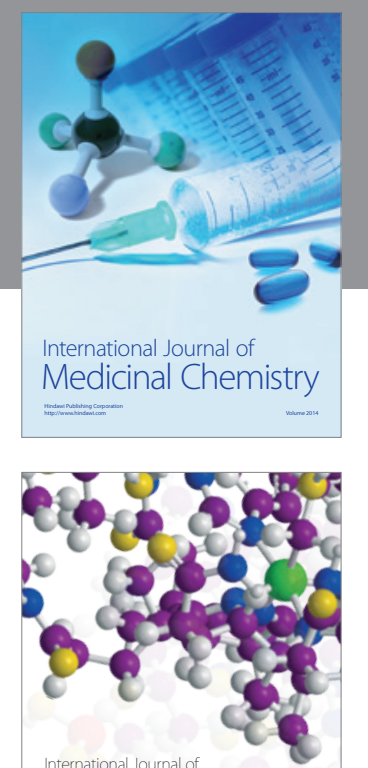

\section{Carbohydrate} Chemistry

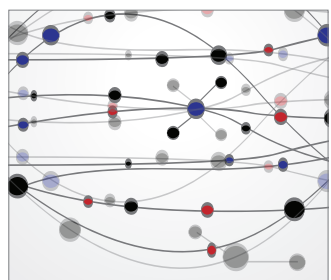

The Scientific World Journal
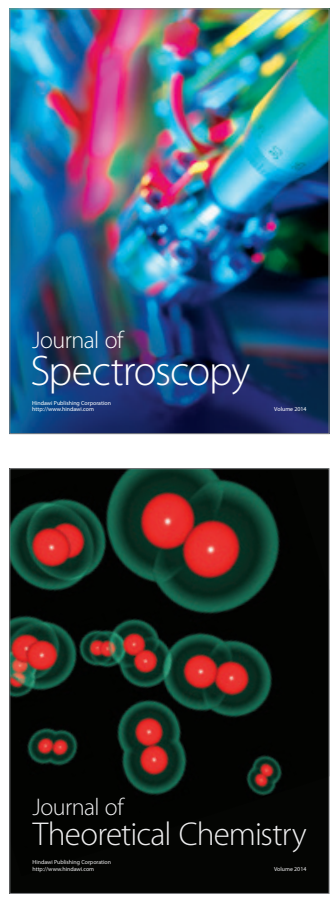
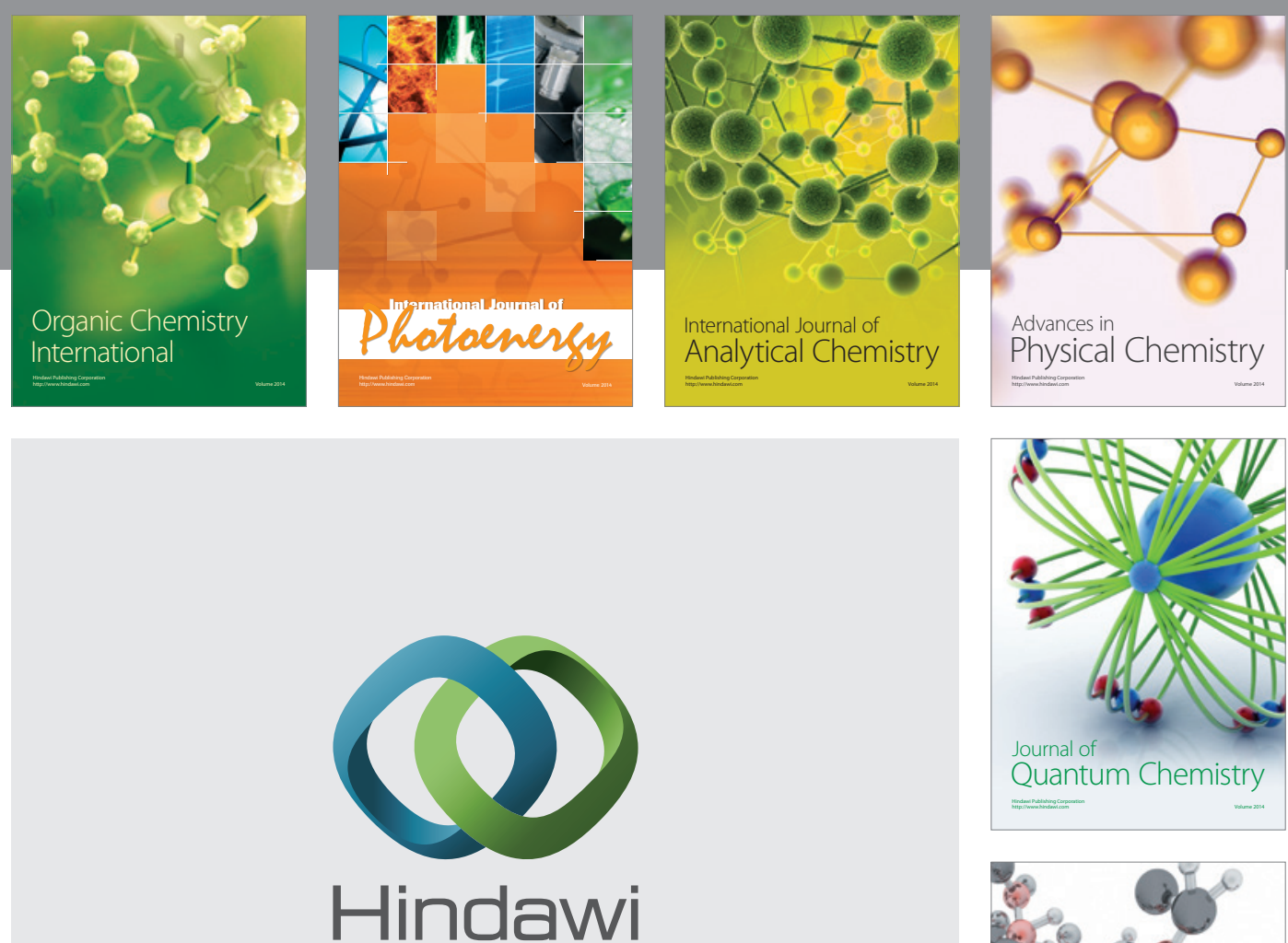

Submit your manuscripts at

http://www.hindawi.com

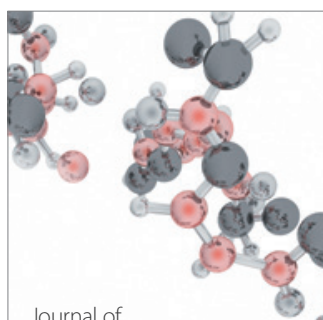

Analytical Methods

in Chemistry

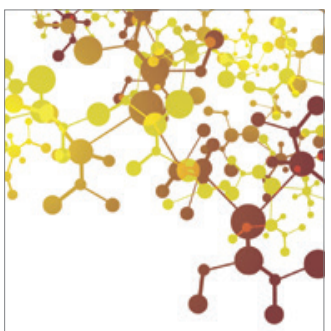

Journal of

Applied Chemistry

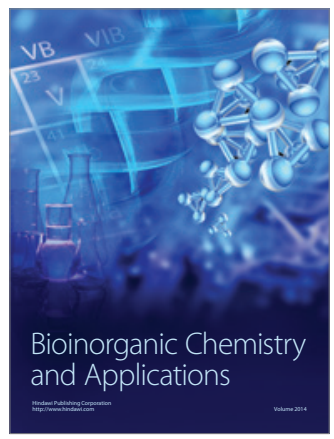

Inorganic Chemistry
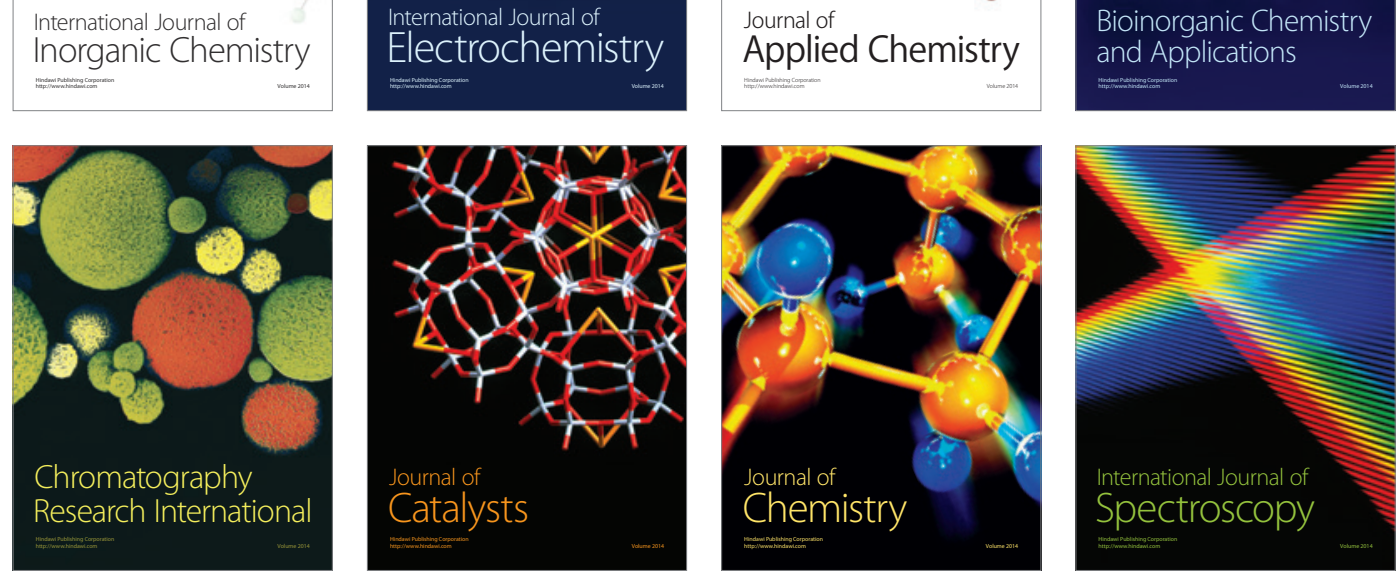